\title{
Formation of Summer Thermocline in the Persian Gulf
}

\author{
Mehdi Delphi and Seyed Majid Mosaddad
}

\begin{abstract}
Thermocline is defined as a sublayer with suddenly decrease in temperature in physical oceanography. Thermocline is often observed in the open ocean and can develop as a seasonal phenomenon in the shallower part of the ocean or as a permanent one that is usually seen in the deeper part of the ocean. Some climate parameters and factors influence on its formation. Such as wind stress, evaporation and solar radiation. Thermocline displacement indicates turbulence happening and internal wave's propagation. The Persian Gulf is a semi-enclosed sea connecting to the Earth surface waters through the Strait of Hormuz. Thermocline exists and forms in the Persian Gulf in summer despite of in winter. In this paper, summer thermocline formation will illustrated [1].
\end{abstract}

Index Terms-Thermocline, Persian Gulf, Summer, Temperature.

\section{INTRODUCTION}

Thermocline is an important phenomenon in physical oceanography and marine physics to be studied. Thermocline forms in different water basins, seas and oceans seasonally. (Mosaddad et al., 2009) shows that summer thermocline form in spite of in winter as a result of temperature uniformity in winter throughout water column in the Persian Gulf. (Kampf and Sadrinasab, 2006) illustrated thermocline development running a numerical modeling applying boundary conditions in the Persian Gulf. Climate changes such as evaporation pointed out to be effective in thermocline formation and changes in (Privett, 1993). Semi-enclosed seas are dynamically of particular interest because they are subject to many of the same forcing as the coastal oceans including both near shore and mid-sea dynamical regimes and a variety of associated mesoscale phenomena. Especially in subtropics excessive evaporation and lake of precipitation lead to hyper saline conditions in the semi-enclosed seas that can drive a thermocline circulation between them and the open sea. Wind stress over these water bodies can change seasonally resulting in substantial annual variation [3]. The outflow of the semi-enclosed sea to the open ocean can increase the salinity of the thermocline. For example, the Persian Gulf outflow increases the salinity of the Oman Sea at the thermocline by approximately $5(\mathrm{psu})$ throughout the thermocline before reaching the western part of the Indian Ocean. The salinity levels within the neighboring thermoclines are also maintained by the regional excess of evaporation over precipitation.

\section{MATERIAL AND METHOD}

Thermocline is marked with temperature break in subsurface decreasingly suddenly, In order to showing thermocline formation in a water column as temperature decease suddenly with a high gradient furthermore salinity increasing in spite of uniformity of temperature and salinity when thermocline doesn't form. Using temperature and salinity data collected in 1992 by Mt. Mitchell all over the Persian Gulf waters in 100 Stations [2]. Drawing temperature and salinity profiles by Excel, we recognize thermocline formation in summer only. Many factors are effective in thermocline formation. We can name some of the as: evaporation, solar radiation, wind stress and water debies from the Gulf of Oman and Arvand river in eastern and northern parts of the Persian Gulf, respectively. However in summer time the thermocline is well established and extends well into the gulf. The main reasons for the formation of the thermocline in summer are strong solar heating and more importantly the diminishing northwesterly winds which are very strong in winter time. During summer the layer below the thermocline is similar in character to the deep water in winter [7]. Above the thermocline the temperature in summer is also much higher.

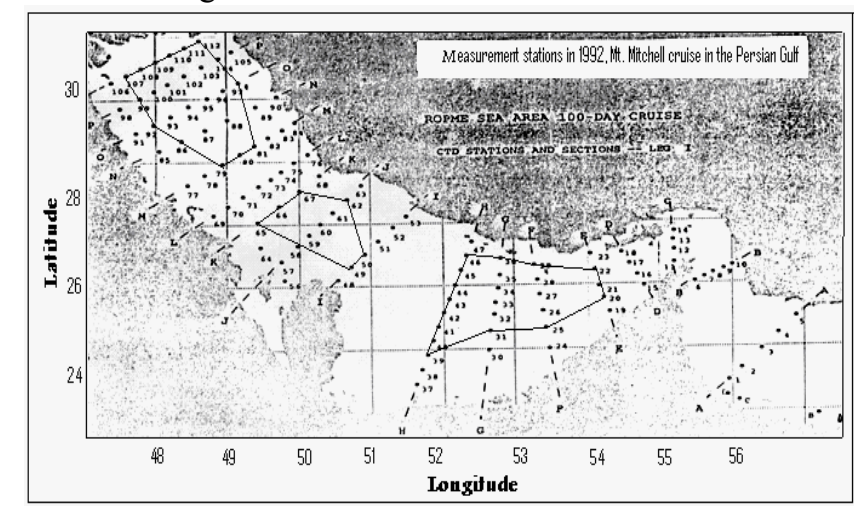

Fig.1 Measurement stations in the Persian Gulf in 1992 climate parameters and factors.

The Persian Gulf as a semiarid zone and semi-enclosed sea in south of Iran in vicinity of Arabian countries includes some of climate factors affecting on the matter. Table1 shows monthly values of such factor from winter to summer. 
TABLE1. Climate factors in the Persian Gulf.

\begin{tabular}{llccc}
\hline Month & $\begin{array}{c}\text { Wind-u } \\
(\mathrm{m} / \mathrm{s})\end{array}$ & $\begin{array}{c}\text { Wind-v } \\
(\mathrm{m} / \mathrm{s})\end{array}$ & $\begin{array}{c}\text { Solar radiation } \\
\left.\text { (w/m }^{2}\right)\end{array}$ & $\begin{array}{c}\text { Evaporation } \\
(\mathrm{mm} / \mathrm{m} / \mathrm{min})\end{array}$ \\
\hline $\mathrm{F}$ & 1.75 & -3.12 & 85 & 0.028 \\
$\mathrm{M}$ & 1.86 & -3.86 & 87 & 0.016 \\
$\mathrm{~A}$ & 1.89 & -4.82 & 132 & 0.014 \\
$\mathrm{M}$ & 1.94 & -5.47 & 179 & 0.013 \\
$\mathrm{~J}$ & 2.03 & -4.87 & 287 & 0.015 \\
$\mathrm{~J}$ & 1.4 & -4.5 & 299 & 0.022 \\
\hline
\end{tabular}

Summer thermocline creates strong stratification near the surface leading to a strong barrier against the vertical exchanges between the surface water and deeper regions. In such a situation the environment is prone to formation of internal waves due to different factors tidal flow over bottom topography, flow around the island and wind disturbances near the surface. Internal waves can break [5]. Breaking of internal waves is the only mechanism in the strongly stratified fluid as in the ocean thermocline that can lead to mixing. The strong temperature gradient under surface layer well inside the Persian Gulf represents existence and formation of seasonal thermocline inside the PG [4]. Thermocline always exists in the Strait of Hormuz because of continuous water exchange between the Persian Gulf and the Gulf of Oman. Also water current debies from the Gulf of Oman and Arvand river to the Persian Gulf are 0.17 and 0.03 severdrup and 650 and 350 cubic meter per second, respectively influencing on the phenomenon in the case study zone.

\section{DATA ANALYSIS}

Thermocline forms in a subsurface layer where temperature decreases with depth rapidly. Thermocline as a negative gradient of temperature in sublayer expressing stratification and so internal waves propagation occurs seasonally in the Persian Gulf. Thermocline formation in the PG in summer despite in winter develops from winter to summer influenced by climatic parameters like evaporation and solar radiation and wind stress varying from winter to summer; river inflow in northwest and current inflow in the Strait of Hormuz in east of the case zone influence on stratification and temperature gradient. In stratified water column, internal waves can propagate not only horizontally (as they do along the interface between layers) but vertically as well [6]. That is, in location of river inflow to the PG, water stratifying contains internal waves propagation. Choosing some index measurement stations all over the Persian Gulf water in different zones, northern, mid (deep) and eastern parts, temperature and salinity profiles are obtained there in winter and summer as the following figure.
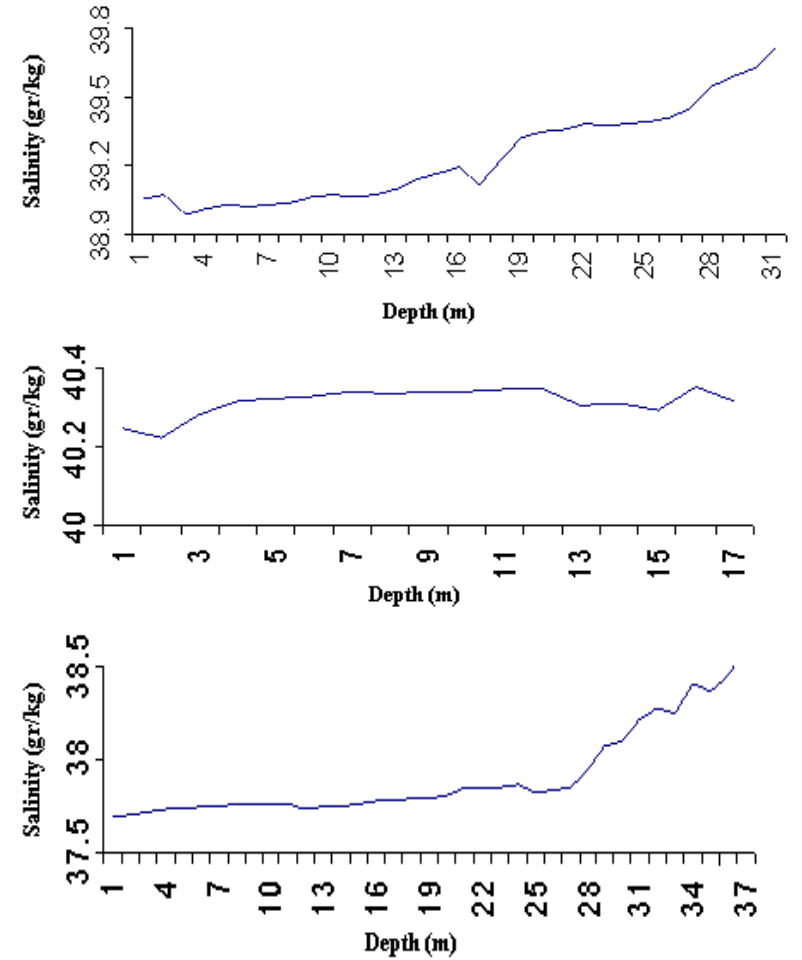

Fig.2 Salinity variation at middle, north and near the strait of Hormoz at Persian Gulf in summer
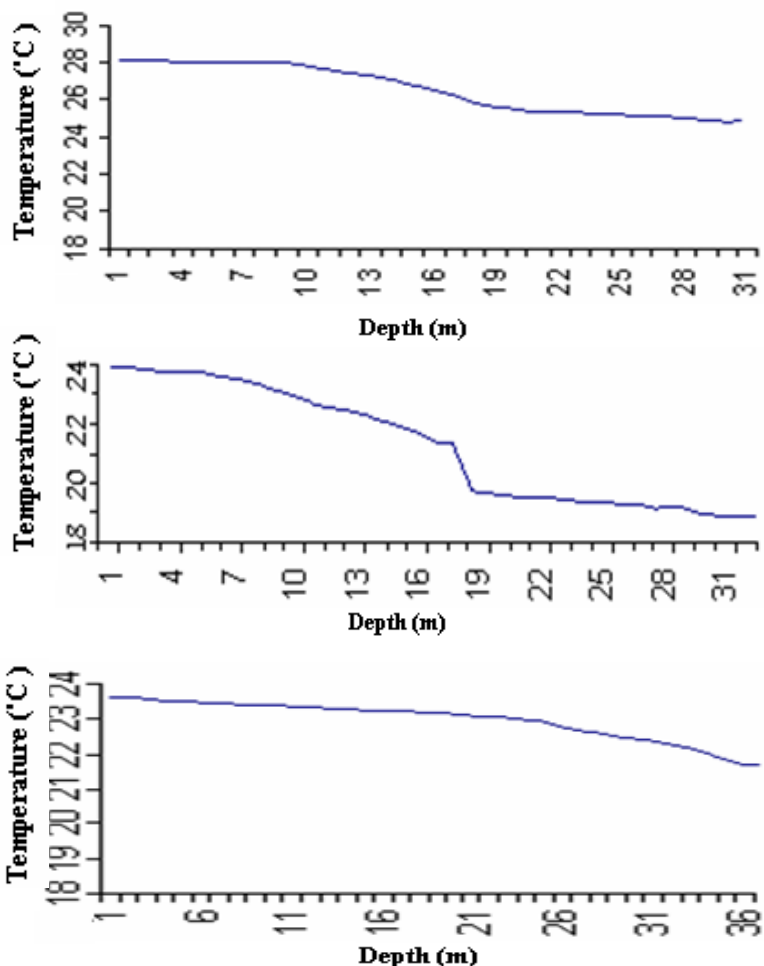

Fig.3 Temperature variation by depth at middle, north and near the strait of Hormoz at Persian Gulf in summer

\section{RESULT AND DISCUSSION}

As we could see in the temperature and salinity contours through latitudinal transects in the Persian Gulf, thermocline can form in summer in spite of winter in whole water of the PG. Numerical modeling of temperature variation from winter to summer shows that river currents of the Arvand, wind stress and evaporation in the northern part of the zone have caused thermocline to be developed so that seasonal 
thermocline form [8]. Thermocline forms in the Strait of Hormoz during year time because of water exchange between the Persian Gulf and the Oman Sea, while as time closes to summer, thermocline extends to north of the Gulf. The Persian Gulf water in Arabian coasts (south of it) is more salty rather than in Iranian coasts (north of it) in summer and it is resulted from higher temperature and shallower water in south of the Persian Gulf and that, salts are taken out of water while evaporating. thermocline extends to north of the Gulf. Some results are as the below:

1) Thermocline forms in all over the Persian Gulf in summer.

2) Temperature hasn't any break or gradient in water column in winter.

3) Climate factors are very effective in thermocline formation in the Persian Gulf.

4) Turbulence happens and internal waves propagate in the Persian Gulf in summer as a result of thermocline displacement in space.

\section{REFERENCES}

[1] Abd Ellah, R. G. E., Thermal Stratification in Lake Nasser, Egypt Using Field Measurements, J. of World Applied Sciences, 2009, Vol. 4, pp. 546-549

[2] Al-Asadi M. S., Talal A. M. and Hreeb K. K., Some ecological studies on hydrophytes from Shatt Al-Arab River, J. of Oceans and Oceanography, 2007, Vol. 2, No.1, pp: 61-68

[3] Alford M.H., Internal swell generation: The spatial energy flux distribution from the wind to mixed layer near-inertial motions, J. of Phys. Oceanography, 2001, Vol. 31, pp: 2359-2368.

[4] Anilkumar N. et. Al., Post-tsunami oceanographic conditions in southern Arabian Sea and Bay of Bengal, J. of Current science, 2006, Vol. 90,No. 3, pp: 421-427.

[5] Emery K. O., Sediment and water of the Persian Gulf, AAPG Bull., 1956, Vol. 40, pp: 2354-2383.

[6] Gordon A. L., Interocean Exchange of Thermocline Water, J. of Geophys. Res., 1986, Vol. 91, No. C4, pp: 5037-5046.

[7] Navrotsky V.V. et. al., Observations of internal waves and thermocline splitting near a shelf break of the Sea of Japan (East Sea), J. of Continental Shel Research, 2004, Vol. 24, Issue 12, pp: 1375-1395.

[8] Shankar D. and Shetye S.R., Why is mean sea level along the Indian coast higher in the Bay of Bengal in the Persian Gulf? J. of Geophysical Research Letters, 2001, Vol.28, No.4, pp.563-565. 